\title{
Energy value of soil organic matter and costs of its restoration
}

\author{
Anna Kuczuk* \\ Opole University of Technology, ul. Prószkowska 76, 45-758, Opole, Poland, a.kuczuk@ po.opole.pl
}

\begin{abstract}
From the point of view of the sustainable soil management, the most important characteristic of soil organic matter (SOM) is associated with the energy content in it. This paper reports the results of an estimation of SOM resources and its energy value for the arable land in a selected farm. For this purpose, soil samples were taken in two fields from a soil depth profile of $30 \mathrm{~cm}$. The testing regarding humus content were conducted at District Chemical and Agricultural Station in Opole. The study involved the assessment of organic matter content at a depth of $30 \mathrm{~cm}$ converted per $1 \mathrm{ha}$, energy value of the SOM resources and the theoretical energy potential was determined. In addition, an example of crop rotation was provided for the analyzed soils, which could be applicable in the process of restoring SOM resources. The cost of restoring the SOM resource was estimated and this value was compared with the energy value of fuel. The total cost of SOM restoration over the period of five years was equal to 3122.26-7845.86 $\mathrm{PLN} \cdot \mathrm{ha}^{-1}$ depending on the value of the lost revenue of commercial production, and simultaneously equal to the value of $6.2-16 \mathrm{Mg}$ thermal coal.
\end{abstract}

\section{Introduction - soil organic matter}

There is a number of various interpretations of the notion of soil organic matter (SOM). Some sources state that SOM is formed by all animals and plant remains both dead and in various stages of decomposition as well as almost completely decomposed humus [1-4]. Other sources also account for the presence of soil organisms in it. In such an approach, SOM is formed by all organic matter in the soil, regardless of its origin and state of decay or alternatively, collection of all carbon compounds in the soil and concurrently coupled with the remaining soil components [5-9]. Sometimes soil organic matter is perceived to be equal to compounds formed by the final decay or even as the organic soil fraction excluding undecomposed organic remains [10].

Since the dead organic matter (organic residue and humus) can form as much as $85-90 \%$ of the total organic matter, with the humus content of up to 70 $80 \%$, of it, very commonly the notions of organic matter and humus are taken as synonyms. For the purposes of this elaboration, an equivalence between the meanings of SOM and humus was adopted.

The functions of the soil organic matter are invaluable both with regard to the soil environment as well as the environment in general. In addition, soil organic matter plays a role in term of the productivity of agriculture. These are two most important functions, which result from the SOM impact on a variety of chemical, physical and biological soil properties $[7,11$, 12]. In particular, the last of these of underestimated in the context of the more numerous and stable populations of microorganisms inhabiting soil that are richer in humus. In turn, their activity promotes the processes of the decomposition of organic matter, which is associated with the supply of valuable nutrients to plants. The colloidal products of the organic matter decay and consequently, the reversed humus contribute to the preservation of soil aggregates $[7,13]$. It is postulated that the soil organic matter content determined the quality and heath of soils. In particular, the light fraction of POM (particulate organic matter) forming the active SOM and subjected to rapid transformations is believed to play the most important role as it provides energy for the biological processes occurring in soils. As given by Flie $\beta$ bach et al. [14], as a consequence of the high content of soil microorganisms, the ratio of the light fraction remains low in the soil. This means that biomass is capable of regulating the organic residue in soil and the amount of this fraction could indicate the level of decay of the organic remains. The environmental role of the soil organic matter reaches far beyond the soil ecosystem. It was demonstrated that there is a considerable relation between the SOM content and heavy metals. Its high content in soils offers a considerable capacity to give an origin to establish bonded forms with metals, thus protecting the soil, water and organic world from the toxic impact of some of the metals [15-17].

The soil organic matter content in soils is given as a result of determination of soil organic carbon $\left(\mathrm{C}_{\mathrm{org}}\right)$, On average it forms $58 \%$ of its composition. Soil forms a considerable reservoir and therefore becomes the potential source of $\mathrm{CO}_{2}$, which is released during decomposition in a similar manner to energy, water and nutrients available for plants. Some soils can lose as much as from 20 to 80 tons of carbon per 1 ha, which is principally emitted into the atmosphere [18].

*Corresponding author: a.kuczuk@po.opole.pl 
The content of soil organic matter varies according to the type of the soil. For example, for the agricultural land, the lowest $\mathrm{C}_{\text {org. }}$ content is noted for the case of chernozem (1.5-2.3\%), whereas the lowest values are noted in luvisols (0.5-1.3\%) [7]. Even a precautionary approach to the study of organic carbon $\mathrm{C}_{\text {org. }}$ in soils suggests that its worldwide resource are in the excess of $1.5 \mathrm{E}+12 \mathrm{Mg}[18,19]$. In the steady state, the volume of the $\mathrm{CO}_{2}$ released into the atmosphere can be equal to $7.50 \mathrm{E}+10 \mathrm{Mg}$ annually, of which human activity contributes to the emission of around $8.0 \mathrm{E}+08 \mathrm{Mg}$ annually. We can note at this point that the soils subjected to agricultural production most commonly lose $20-50 \%$ of the carbon content in them [19].

The purpose of this article is to evaluate the content of SOM in soil samples taken from selected arable land. Besides, its energetic value was estimated, and cost of SOM restoration. It was noted that the soil can be a reservoir for significant amounts of energy, which is essential to sustaining the metabolic processes. By determining the value of the costs for SOM restoring, its value was referred to the value of thermal coal.

\subsection{Energy accumulated by soil organic matter}

From the point of view of the biological function performed by soil organic matter, beside the supply of nutrients, it forms a source of considerable amounts of potential energy. This energy can be perceived as:

a) energy of the accumulated organic material forming the soil organic matter,

b) metabolic energy, which drives the biological processes and originating from the organic material decomposed in the soil.

In fact, the two types of the energy accumulated in the soil organic matter are equivalent. They both originate in the solar energy and the process of photosynthesis, and the energy accumulated in the organic matter forms a resource comprising nutrients and energy needed for the functions of the soil organisms.

The metabolic energy is directly linked to the carbon cycle in the environment: use of $\mathrm{CO}_{2}$ from the atmosphere by autotrophs, primary production, secondary production and finally decomposition of dead organic matter and reversal of certain amounts of energy (mainly in the form of heat) and return of $\mathrm{CO}_{2}$ again into the atmosphere (respiration) and accumulation of carbon in the soil in the form of stabilized compounds. The decomposition process involving organic matter is estimated to produce heat, which is expressed as an equivalent of carbon with the value of 1-12 tons per 1 ha, depending on the type of agricultural production [20].

The content of energy in SOM can vary depending on the type of the organic material delivered into the soil. Graham and Sanger [21] identified clear differences in the caloric value of SOM depending on the type of the habitat. In the humus layer of the forested areas, it is equal to $5.04 \mathrm{kcal} \cdot \mathrm{g}^{-1}(21.17$
$\left.\mathrm{MJ} \cdot \mathrm{kg}^{-1}\right)$, whereas in marshy soils $-4.87 \mathrm{kcal} \cdot \mathrm{g}^{-1}(20.41$ $\left.\mathrm{MJ} \cdot \mathrm{kg}^{-1}\right)$, and in mud soils in ponds and lakes -5.24 $\mathrm{kcal} \cdot \mathrm{g}^{-1}\left(21.9620 .41 \mathrm{MJ} \cdot \mathrm{kg}^{-1}\right)$. Concurrently, the energy value of the organic matter of the soil in forested areas corresponds to the mean value for the majority of soils. Similar results are offered by insight provided in other reports in the area [13, 22, 23].

Under the assumption of the above, the energy value of the soil organic matter can be expressed in terms of fuel equivalent (thermal or anthracite coal). Apparently, such a comparison is strictly theoretical. The energy value of the SOM only plays a role in the metabolic processes occurring in soils, and it does not directly serve economic purposes in terms of energy production. Even a comparison of the energy density of fuels (thermal coal: $24 \mathrm{MJ} \cdot \mathrm{kg}^{-1}$, anthracite coal: 32.5 $\mathrm{MJ} \cdot \mathrm{kg}^{-1}$ ) and soil (e.g. for the $\mathrm{C}_{\text {org. }}$ content $=2 \%: 0.66$ $\mathrm{MJ} \cdot \mathrm{kg}^{-1}$ of soil) demonstrates the existence of considerable differences in the energy potential. Such a comparison also reveals the existence of a pool of the energy gathered in the soil and the value of the energy potential of the organic matter. It can be different depending on the type of soil. In the chernozem in the arable land, for the content of $\mathrm{C}_{\text {org. }}$ equal to $1.5-2.3 \%$, the resources of the SOM are equal to 200-270 tons $\cdot \mathrm{ha}^{-1}$. For luvisols, for the content of $\mathrm{C}_{\text {org. }}$ equal to $0.5-1.3 \%$, it is $30-90$ ton $\cdot \mathrm{ha}^{-1}$ [7]. Therefore, such soils have different energy values corresponded to the heat, that can be derived from the combustion of 140 and $35.6 \mathrm{Mg}$ of anthracite coal, respectively.

The quality and health of soils are relative to the high organic matter content in them. From the point of view of the maintenance of its high and constant level, it is necessary to ensure that the rate of the respiration process does not exceed the accumulation of carbon in soils [12]. Such conditions guarantee the maintenance of the nutritional (energy) demand of the soil organisms, while concurrently determines the effective course of the biological processes in them as well as decides on the health and quality of the soil.

Under the assumption of adequate soil management, the high content of the soil organic matter contributes to the accumulation of considerable amounts of stable forms of carbon (as humus) as well as improves physical and chemical properties of soils. As a consequence, energy in preserved in the stable form of SOM, which is subjected to continuous decomposition leading to the release of the nutrients available for plants. Hence, from the perspective of sustainable agricultural production, the maintenance of a steady supply of the organic matter to soil and the accumulation of SOM (energy) can be considered as an investment in the soil capital [24, 25]. Cong et al. [26] emphasize that the natural soil capital, which is represented by the soil organic carbon resource, can mitigate a number of threats facing the agriculture in the future. Crop diversification and primarily, the correct management of the soil organic matter can contribute to the increase of farm revenues and limit the future agricultural hazards, resulting from e.g. price fluctuations and variable weather conditions. All this is 
due to the direct relations between the biological soil diversity and the constant supply of organic matter.

\section{Materials and methods}

Soil samples were extracted from two arable lands with the purpose of estimating the energy value of SOM. The fields applied for the collection of soil samples are situated in the Opole province, Krapkowice commune. The surface area of the fields is as follows:

a) field A: 1.40 ha;

b) field B: 0.62 ha.

On the areas subjected to the analysis, the dominant crops include grains, maize and rape, which are listed as plants with a potential to degrade the soil organic matter. The crop rotation includes the use of cereallegumes mixtures and ploughing down catch crops.

For each of the soil, laboratory testing (by accredited District Chemical and Agricultural Station in Opole) was performed with the purpose of determining granulometric composition (the Prószyński method), as well as content of humus (the Tiurin method) and total nitrogen $\left(\mathrm{N}_{\text {tot. }}\right.$, the Kjeldahl method). The measurements of the bulk density [27] of the soils was also performed with the purpose of determining the humus content. The soil samples were taken over the period comprising 2014 and 2015. The samples in each field were extracted two times every year (before introduction of fertilizers and after the main crop was harvested). The first extraction was performed in March 2014, whereas the final - in September 2015. Due to the short duration of the tests and the small number of samples, the laboratory tests were aimed at determination of the mean SOM content and $\mathrm{N}_{\text {tot. }}$ for the period involving two years.

The assessment of the organic matter resource was performed for the soil depth profile of $0-30 \mathrm{~cm}$. In addition, information was gathered for each farm regarding the sowings and amount of organic matter that is supplemented into the soil.

For the purpose of determination of the energy value of SOM, it was assumed that the content of the organic matter is equal to $4.7 \mathrm{kcal} \cdot \mathrm{g}^{-1}\left(19.7 \mathrm{MJ} \cdot \mathrm{kg}^{-1}\right)$ [23]. This was coupled with determination of its energy potential. The resource of the organic matter was established for the soil depth profile of $0-30 \mathrm{~cm}$, together with the energy value expressed in $\mathrm{MJ} \cdot \mathrm{ha}^{-1}$, and the theoretical energy potential expressed as an equivalent of thermal fuel. The study focused attention on the relation between the crop structure and type of organic matter introduced into the soil and the existence of the variable amounts of the organic matter in the soil itself.

The results of the calculation encouraged the author to draw up a detailed scenario regarding the activities required to restore the organic matter content in soils. This was coupled with the estimation of an approximate cost that it needed to restore the soil organic matter by comparing it with the value of the thermal coal.

For this scenario the balance of SOM was calculated [28] and the amount of the required organic material for SOM restoring during five years. The estimated costs of SOM restoring include the chosen expenditures spent on soil-enriching plants and the value of added manure. In addition, the lost revenues and the avoiding costs of discarding the crop (wheat) were calculated [29-31].

\section{Results and discussion}

\subsection{Energy accumulated in soil organic matter and its potential}

The basic information derived from laboratory analysis involving soil samples and crops in the analyzed fields are summarized in Tables 1 and 2 .

The analysis of the granulometric composition provided the information needed to determine the granulometric groups: for fields A and B: sandy loam with considerable fraction of sand by volume $(57 \%$ $60 \%$ ). The bulk densities of the analyzed soils are characterized by low values, which can demonstrate that the air passage through the soil is adequate. Concurrently, these values result from the greater proportion of the sand fraction than from the content of organic matter itself. The values of the densities are however, characteristic for mineral soils.

From the analysis of this data and on the basis of the data from European Soil Bureau [32] we can state that the humus content in the analyzed soils is very low. Such conditions can be hazardous for the quality and health of the soil ecosystem, since the minimum level of $\mathrm{C}_{\text {org. }}$ that is required to sustain the stability of the soil is equal to $2 \%$ [33]. The many years of the analysis conducted by the team at IUNG-PIB [34], concerning the variability of the humus content in farmlands, demonstrate the boundary humus levels of $1.84 \%\left(1.07 \% \mathrm{C}_{\text {org. }}\right)$ for which the volume can remain constant. The soils with the higher humus content tend to lose it, whereas for the case of a lower level - it tends to increase on condition that the cultivation is performed so that the application of sustainable techniques of cultivation. Concurrently, the analysis provided insight into the annual rate of the organic matter loss from the soil at a level of $2.2 \%$.

For the case of the examined soils, there is concurrently a very narrow C:N ratio (around 8:1), which is associated with the low SOM content and attests to the greater amount in nitrogen in the soil. A considerable higher value of this ratio for the case of field $\mathrm{B}$ can be attributed to the introduction of natural fertilizers to it. In both fields, aftercrop (mustard seed) was ploughed down, while in the following year, aftercrop was ploughed down only in the field B. In addition, manure was brought in twice in the amount equal to 35 and $20 \mathrm{Mg} \cdot \mathrm{ha}^{-1}$, respectively (Table 2 ). 
Table 1. Results of laboratory analysis of soil samples, humus content, carbon-to-nitrogen ratio (C:N).

\begin{tabular}{|c|c|c|c|c|c|c|c|c|c|}
\hline \multirow{2}{*}{ Field } & \multirow{2}{*}{ Soil type } & \multirow{2}{*}{$\begin{array}{l}\mathrm{N}_{\text {tot. }} \\
{[\%]} \\
\end{array}$} & \multirow{2}{*}{$\begin{array}{c}\text { Humus } \\
{[\%]} \\
\end{array}$} & \multirow{2}{*}{$\begin{array}{r}\mathrm{C}_{\text {org. }} \\
{[\%]}\end{array}$} & \multirow{2}{*}{$\mathrm{C}: \mathrm{N}$} & \multicolumn{2}{|c|}{ Assessment of $\mathrm{C}_{\text {org. }}$ content } & \multirow{2}{*}{$\begin{array}{c}\text { Mean bulk } \\
\text { density } \\
{\left[\mathrm{g} \cdot \mathrm{cm}^{-3}\right]}\end{array}$} & \multirow{2}{*}{$\begin{array}{c}\text { Humus } \\
\text { resources } \\
{\left[\mathrm{Mg} \cdot \mathrm{ha}^{-1}\right]}\end{array}$} \\
\hline & & & & & & $\begin{array}{l}\text { based on } \\
\text { ESB data }\end{array}$ & $\begin{array}{l}\text { based on } \\
\text { IUNG data }\end{array}$ & & \\
\hline A & \multirow{2}{*}{$\begin{array}{l}\text { sandy } \\
\text { loam }\end{array}$} & 0.12 & 1.568 & 0.91 & $7.6: 1$ & v. low & low & 1.05 & 49.46 \\
\hline $\mathrm{B}$ & & 0.11 & 1.573 & 0.91 & $8.2: 1$ & v. low & low & 1.09 & 51.34 \\
\hline
\end{tabular}

"ESB - European Soil Bureau; ${ }^{* *}$ IUNG-PIB - Institute of Soil Science and Plant Cultivation - State Research Institute

Table 2. Crop rotation, use of natural fertilizers, organic mass ploughed down, 2014-2015.

\begin{tabular}{|c|c|c|}
\hline Year & A & $\mathrm{B}$ \\
\hline 2013 & forecrop - winter wheat - harvested straw & forecrop - potatoes \\
\hline \multirow{3}{*}{2014} & aftercrop- field ploughed in spring & aftercrop - field ploughed in spring \\
\hline & \multirow{2}{*}{$\begin{array}{c}\text { main crop - mixed cereals and grain legumes, } \\
\text { harvested straw }\end{array}$} & manure $-35 \mathrm{Mg} \cdot \mathrm{ha}^{-1}$ \\
\hline & & $\begin{array}{l}\text { main crop - mixed cereals and grain legumes, harvested } \\
\text { straw }\end{array}$ \\
\hline \multirow{3}{*}{2015} & \multirow{3}{*}{ main crop - rape: harvested straw } & aftercrop - field ploughed in spring \\
\hline & & manure $-20 \mathrm{Mg} \cdot \mathrm{ha}^{-1}$ \\
\hline & & mixed cereal seeds - harvested straw \\
\hline
\end{tabular}

The application of the simplified assessment of the balance of SOM conducted by application of the reproduction and degradation coefficients by Eich and Kundler [28] demonstrate the loss of organic matter in field A $\left(-0.01 \mathrm{Mg} \cdot \mathrm{ha}^{-1}\right)$ and its increase in field B $\left(+8.45 \mathrm{Mg} \cdot \mathrm{ha}^{-1}\right)$ (Table 3$)$. The results of laboratory analysis also demonstrate the changes in such a direction. Due to the fact that it does not account for the depth of the cultivation profile [35] and other parameter with a potential effect on the SOM content in soil (e.g. temperature, mineralization rate, water, water storage capabilities, amounts and diversity of soil organisms), such simplified assessment cannot give precise results. The results can only be applied with the purpose of the correct crop rotation in terms of the maintenance of a positive balance of the organic matter. More precise results are provided by the results of measurements with regard to humus content by application of laboratory test carried over a long-term span.

The resources of humus accumulated in the analyzed soil are characteristic for arable lands e.g. luvisols and brown soils [7, 36]. In turn, the energy accumulated in SOM results both from its total volume in the soils as well as from the type of the organic matter introduced into the soil. For the analyzed fields, the value of energy in SOM and expressed in $\mathrm{MJ} \cdot \mathrm{ha}^{-1}$ is in the range from $9.74 \mathrm{E}+05$ to $1.01 \mathrm{E}+06$. These values correspond to the amount of heat that can be gained from combustion of 40.58-42.08 Mg of thermal coal, with a caloric value of $24 \mathrm{MJ} \cdot \mathrm{kg}^{-1}$ (Table 4). The energy accumulated in SOM seems to be considerable, however, it has a potential for application only in the sense of biogeochemical transformations due to its considerable dissipation. For the case of soils with the greater and concurrently more desirable fraction of organic matter, e.g. $4 \%$, its energy value is relatively greeter and equal to $3.94 \mathrm{E}+06 \mathrm{MJ} \cdot \mathrm{ha}^{-1}$ [37].

Table 3. Organic matter balance for the examined soil for the period 2014-2015.

\begin{tabular}{|c|c|c|c|c|c|}
\hline \multirow[t]{2}{*}{ Field } & \multicolumn{3}{|c|}{$\begin{array}{c}\text { Reproduction }(+) \text { or } \\
\text { degradation }(-) \text { of organic } \\
\text { matter }[\mathrm{Mg}]\end{array}$} & \multirow{2}{*}{$\begin{array}{c}\text { Loss/gain } \\
\text { of } \\
\text { organic } \\
\text { matter } \\
{[\mathrm{Mg}]}\end{array}$} & \multirow{2}{*}{ 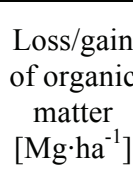 } \\
\hline & $\begin{array}{l}\text { aftercrop } \\
\text { ploughed }\end{array}$ & manure & $\begin{array}{l}\text { main } \\
\text { crop }\end{array}$ & & \\
\hline A & +0.98 & 0.00 & $\begin{array}{l}-0.74 \\
+0.49 \\
-0.74\end{array}$ & -0.01 & -0.01 \\
\hline B & $\begin{array}{l}+0.43 \\
+0.43\end{array}$ & $\begin{array}{l}+3.06 \\
+1.75\end{array}$ & $\begin{array}{l}-0.33 \\
+0.22 \\
-0.33\end{array}$ & +2.52 & +8.45 \\
\hline
\end{tabular}

Table 4. SOM resources, its energy and energy value expressed as an equivalent of thermal coal, mean results for 2014-2015.

\begin{tabular}{|c|c|c|c|}
\hline Field & $\begin{array}{c}\text { Resources } \\
\text { of organic } \\
\text { matter } \\
{\left[\mathrm{Mg} \cdot \mathrm{ha}^{-1}\right]}\end{array}$ & $\begin{array}{c}\text { Energy } \\
\text { resources in } \\
\text { soil organic } \\
\text { matter } \\
{\left[\mathrm{MJ} \cdot \mathrm{ha}^{-1}\right]}\end{array}$ & $\begin{array}{c}\text { Energy value of } \\
\text { organic matter } \\
\text { as equivalent to } \\
\text { thermal coal } \\
{[\mathrm{Mg}]}\end{array}$ \\
\hline A & 49.46 & $9.74 \mathrm{E}+05$ & 40.58 \\
\hline B & 51.34 & $1.01 \mathrm{E}+06$ & 42.08 \\
\hline
\end{tabular}


The results concurrently indicate the theoretical energy potential accumulated in the organic matter when the results of the calculations are compared with the cumulative energy intensity of the selected types of farm production (Table 5). Depending on the intensity of the production as well as involved means of production and types of crops, the value of the energy intensity can be different.

From the data in the table, we can see that theoretically - energy accumulated in the organic matter of the analyzed soils could constitute an equivalent of the energy used for the production of various crops over the period of long years to come. For example, the SOM energy resources (for analyzed soils) are theoretically equivalent to the energy consumption of organic buckwheat production during 91-95 years. In the case of conventional wheat cultivation, depending on the intensity of production, the SOM energy is theoretically equivalent to the energy that could be used for a period of 41-86 years in wheat cultivation.

Table 5. Energy input in production and theoretical potential of soil organic matter.

\begin{tabular}{|c|c|c|c|}
\hline \multirow[t]{2}{*}{ Production } & \multirow[t]{2}{*}{$\begin{array}{l}\text { Energy input } \\
{\left[\mathrm{MJ} \cdot \mathrm{ha}^{-1} \cdot \mathrm{y}^{-1}\right]}\end{array}$} & \multicolumn{2}{|c|}{$\begin{array}{l}\text { Theoretical energy } \\
\text { potential of SOM } \\
\text { equivalent to } \\
\text { energy intensity during } \\
\text { the years of production }\end{array}$} \\
\hline & & A & B \\
\hline $\begin{array}{l}\text { Winter wheat } \\
\text { (USA) }\end{array}$ & $1.77 \mathrm{E}+04$ & 55 & 57 \\
\hline Wheat (India) ${ }^{*}$ & $1.18 \mathrm{E}+04$ & 83 & 86 \\
\hline $\begin{array}{c}\text { Corn - } \\
\text { conventional } \\
\text { (USA)** }\end{array}$ & $3.26 \mathrm{E}+04$ & 30 & 31 \\
\hline $\begin{array}{l}\text { Corn - } \\
\text { organic } \\
(\text { USA) })^{* *}\end{array}$ & $2.25 \mathrm{E}+04$ & 43 & 45 \\
\hline $\begin{array}{l}\text { Soyabean - } \\
\text { organic } \\
\text { (USA) }{ }^{* * *}\end{array}$ & $1.05 \mathrm{E}+04$ & 93 & 96 \\
\hline $\begin{array}{c}\text { Soyabean - } \\
\text { conventional } \\
(\text { USA)** }\end{array}$ & $1.26 \mathrm{E}+04$ & 77 & 80 \\
\hline $\begin{array}{l}\text { Winter wheat } \\
\text { - conventional } \\
\text { (Poland) }\end{array}$ & $2.39 \mathrm{E}+04$ & 41 & 42 \\
\hline $\begin{array}{c}\text { Winter wheat } \\
\text { - organic } \\
\text { (Poland) }\end{array}$ & $1.12 \mathrm{E}+04$ & 87 & 90 \\
\hline $\begin{array}{l}\text { Buckwheat - } \\
\text { conventional } \\
\text { (Poland) }\end{array}$ & $7.97 \mathrm{E}+03$ & 122 & 127 \\
\hline $\begin{array}{l}\text { Buckwheat - } \\
\text { organic } \\
\text { (Poland) }{ }^{* * * * *}\end{array}$ & $1.07 \mathrm{E}+04$ & 91 & 95 \\
\hline
\end{tabular}

\subsection{Cost of restoring SOM}

Since the content of organic matter (and $\mathrm{C}_{\text {org. }}$ ) in the analyzed fields is very low, it is necessary to ensure that measures are taken so as to protect the soil resources. For the case of arable land, it needs to be based on an adequately selected crop rotation including long plant alternation, including leguminous fodder plants, grass, introduction of mineral fertilizers, ploughing down green masses and reduced tillage. In extreme case, the restoration of soil capital needs to involve excluding land from production of crops for many years, which consequently results in the loss of revenues. In reality, in particular in large commercial farms, whose aim is to gain profits within a short time span, such activities are rarely employed. Although the crop rotations involving extended periods of plant alternation can contribute to the greater benefits than the shorter periods, such as two years [42], the majority of farms apply short plant alternation cycles, in which the dominant role is played by cereal plants.

Under the assumption of the annual rate of organic matter loss equal to $2.2 \%$ [34], we need to primarily attempt to stop its degradation. For the analyzed fields this means the necessity of supplementing additional amounts of organic matter equal to around $1 \mathrm{Mg}$ annually. This should not intervene in the normal operation of a commercial farm. Clearly, when we consider restoring the organic matter content in soils to the level determined by ESB, which corresponds to the level that is safe for the soil ecosystem $(\mathrm{SOM} \geq 3.5 \%$; $\mathrm{C}_{\text {org. }} \geq 2 \%$ ), or at least to the level given by IUNG-PIB $\left(\mathrm{SOM} \geq 1.84 \% ; \mathrm{C}_{\text {org. }}=1.07 \%\right)$, we have to realize that the process will take a long time, and this involves the need to set aside the arable land from commercial production for a certain period in time.

An estimate regarding the cost of restoring soil organic matter in the analyzed soils should account for the value of the necessary procedures that have to be taken and the use of adequate means of production along with the lost revenues resulting from the land setaside from production. Table 6 contains an example of crop rotation determined for the period including five years. From the calculated and simplified soil organic matter balance, we know that within 5 years the soil can gain around $6.5 \mathrm{Mg}$ of organic matter (i.e. $1.3 \mathrm{Mg}$ per year) on average; however, this calculation does not account for the losses resulting from mineralization. Such an amount corresponds to the amount that is indispensable for the removal of the impact of its annual losses. Hence, the restoration of SOM to its higher levels requires longer periods of time accounting for the time when the land is set aside from commercial production coupled with the introduction of greater volumes of organic and natural fertilizers. Concurrently, we need to bear in mind the admissible levels that do not pose a hazard to the environment.

On the basis of selected information derived from calculations performed by Warmia-Mazury Agricultural Advisory Centre, an estimation of the approximated cost which is indispensable to introduce the necessary amount of the organic matter into the soil. This calculation accounted for the value of manure, clover seeds, accompanying work during the introduction of manure and clover cultivation. 
The cost that was incurred is equal to 3852.66 PLN $\cdot \mathrm{ha}^{-1}$ over the period of five years. By accounting for the loss revenue from the set aside land (capable of producing wheat in III and IV year), on the basis of the 2016 wheat price $\left(612.60 \mathrm{PLN} \cdot \mathrm{t}^{-1}\right)$, we can conclude that the cost of restoration is equal to $3122.26 \mathrm{PLN} \cdot \mathrm{ha}^{-1}$ (excluding agricultural payments). The price of the wheat seed was at a relatively low level, which resulted in losses from commercial plant production $(-730.40$ PLN.ha $\left.{ }^{-1}\right]$. The production of clover with the purpose of restoring organic matter proves profitable in such circumstances. This is due to the fact that it leads to minimization of the agricultural risk, as stated by Cong et al. [26].

Table 6. Example of crop rotation coupled with the cost of restoring soil organic matter.

\begin{tabular}{|c|c|c|c|c|}
\hline \multicolumn{5}{|c|}{ Years } \\
\hline I & II & III & IV & V \\
\hline $\begin{array}{c}\text { roots } \\
+35 \text { tons } \\
\text { of } \\
\text { manure }\end{array}$ & $\begin{array}{c}\text { spring barley } \\
+ \\
\text { undersown } \\
\text { clover, } \\
\text { straw } \\
\text { collected for } \\
\text { litter } \\
\end{array}$ & clover & clover & $\begin{array}{c}\text { winter } \\
\text { wheat, } \\
\text { straw is } \\
\text { harvested } \\
\text { for litter }\end{array}$ \\
\hline \multicolumn{5}{|c|}{ Balance of organic matter, $\mathrm{Mg} \cdot \mathrm{ha}^{-1}$} \\
\hline+1.66 & +1.43 & +1.96 & +1.96 & -0.53 \\
\hline \multicolumn{5}{|c|}{ Total: $6.48 \mathrm{Mg} \cdot \mathrm{ha}^{-1}=$ mean $1.3 \mathrm{Mg} \cdot \mathrm{ha}^{-1} \cdot$ year $^{-1}$} \\
\hline \multicolumn{5}{|c|}{$\begin{array}{l}\text { Restoration cost involving prices as of } 2016^{*}\left[\mathrm{PLN} \cdot \mathrm{ha}^{-1}\right] \\
\text { calculated for the period of } 5 \text { years }\end{array}$} \\
\hline \multicolumn{2}{|c|}{ Cost incurred } & \multicolumn{3}{|c|}{$\begin{array}{l}\text { Lost revenues from stopping } \\
\text { wheat production }\end{array}$} \\
\hline \multirow{3}{*}{\multicolumn{2}{|c|}{3852.66}} & \multicolumn{3}{|c|}{$\begin{array}{l}-730.40 \text { (for wheat price of } \\
612.60 \mathrm{PLN} \cdot \mathrm{t}^{-1} \text { ) }\end{array}$} \\
\hline & & \multicolumn{3}{|c|}{$\begin{array}{l}2593.20 \text { (for wheat price of } \\
850.0 \text { PLN } \cdot \mathrm{t}^{-1} \text { ) }\end{array}$} \\
\hline & & \multicolumn{3}{|c|}{$\begin{array}{l}3993.20(\text { for wheat price of } \\
\text { 950 PLN } \cdot \mathrm{t}^{-1} \text { ) }\end{array}$} \\
\hline \multicolumn{5}{|c|}{$\begin{array}{c}\text { Total restoration cost }\left[\mathrm{PLN} \cdot \mathrm{ha}^{-1}\right] \text { calculated for the period } \\
\text { of five years }\end{array}$} \\
\hline \multicolumn{5}{|c|}{3122.26} \\
\hline \multicolumn{5}{|c|}{6445.86} \\
\hline \multicolumn{5}{|c|}{7845.86} \\
\hline
\end{tabular}

"Estimate on the basis of selected agricultural calculations performed by: Warmia-Mazury Agricultural Advisory Centre [29-31]; the mean price of 1 ton of manure on the basis of information gained from agricultural portals.

Since farmers are interested in gaining both high efficiency of production, as well as high revenues, the calculations were additionally conducted for two price alternatives: 850.0 and $950.0 \mathrm{PLN} \cdot \mathrm{t}^{-1}$. The adoption of higher prices results in the increase of the restoration cost more than twice.

The values of the cost incurred in connection of restoring the organic matter can be compared with prices of thermal coal. Under the assumption that the cost of one $\mathrm{Mg}$ of thermal coal is $500 \mathrm{PLN} \cdot \mathrm{Mg}^{-1}$, the

value of restoring the degraded resource of SOM (6.5 $\mathrm{Mg}$ ) is equal to the value of $6.2-16 \mathrm{Mg}$ of thermal coal depending on the adopted scenario of lost revenues.

\section{Conclusions}

The results of the research offer the statement of the following conclusions.

Soil organic matter forms a resource whose role determines the capability of agricultural production. It forms a reservoir containing considerable amounts of carbon and this is the principal role that it plays in the environment. It also forms a dispersed yet relevant energy resource (from the point of view of agricultural production and environment).

In general, soils in Poland are poor in terms of the organic matter content. This is also the case for the analyzed fields, where its resources are equal to 49.46 and $51.34 \mathrm{Mg} \cdot \mathrm{ha}^{-1}$, respectively, and $\mathrm{C}_{\text {org. }}$ was determined at a level of $0.91 \%$.

Despite this, the potential accumulated in the analyzed soils is in the range of $9.74 \mathrm{E}+05-1.01 \mathrm{E}+06 \mathrm{MJ} \cdot \mathrm{ha}^{-1}$, which corresponds to the potential of around $40 \mathrm{Mg}$ of thermal coal.

On the basis of a comparison of this potential with the energy efficiency of various types of agricultural production, we can state that it could contribute the required energy input over the period of tens of years to come.

The restoration of an adequate and safe environmental level of SOM is associated with a long and cost generating enterprise. As demonstrated by the adopted scenario of activity, the attempt at introducing $6.5 \mathrm{Mg}$ of organic matter over five years results in the generation of a considerable cost.

This, in turn, results from the application of adequate means of production and operations as well as lost revenues from production that was not obtained from set aside land.

For the developed scenario, the total cost of SOM restoration over the period of five years was equal to 3122.26-7845.86 PLN $\cdot \mathrm{ha}^{-1}$ depending on the value of the lost revenue from wheat production.

The total value of the lost SOM restoring is simultaneously equal to the value of $6.2-16 \mathrm{Mg}$ thermal coal, depending on price of a wheat commercial production.

Under conditions of predicting of low wheat prices (or other agricultural risks), the farmers may consider temporary exclusion of arable land from commercial production for the purpose of renewing the soil organic matter.

The costs incurred to enrich the soil in organic matter (3122.26 PLN ha ${ }^{-1}$ ) appear to be relatively higher than the potential loss in revenue from commercial production $\left(-730.40 \mathrm{PLN} \cdot \mathrm{ha}^{-1}\right)$. However, the expenditures on organic matter contribute to 
improving the quality and health of the soil over an extended period of time.

\section{References}

1. G.D. Buchan, J. Soil and Water Cons. 65, 2, 48A54A (2010)

2. H. Dziadowiec, Glebowa materia ogranicza pojęcia podstawowe (in): Badania ekologicznogleboznawcze [red. Bednarek R $\mathrm{i}$ in.]. PWN, Warszawa (2005)

3. M.M. Kononova, Soil organic matter. Its nature, its role in soil. Formation and soil fertility. The Acad. of Soil Sci. USSR. The V.V. Dokuchaev Soil Institute. Izd. Akad. Nauk. SSSR. Moscow (1966)

4. R.J. Manlay, Ch. Feller, M.J. Swift, Agric. Ecosyst. Environ. 119, 217-233 (2007)

5. J.A. Baldock, J.O. Skjemstad, Soil organic carbon/soil organic matter, (in): Soils analysis: an Interpretation Manual, [Eds K. I. Peverill, L.A. Sparrow, D.J. Reuter.], CSIRO Publ.: Collingwood (1999)

6. A. Bot, J. Benites, The importance of soil organic matter - Key to drought-resistant soil and sustained food production, FAO Soils Bull. 80 (2005)

7. S. Gonet, H. Smal, J. Chojnicki, Materia organiczna gleb (in): Gleboznawstwo (red. Mocek A.), PWN (2015)

8. W. Horwath, Carbon cycling: the dynamics and formation of organic matter. Chapter 12, (in): Soil microbiology, Ecology and Biochemistry (red. Paul E.A.). 4th Edition. Nat. Res. Ecol. Lab. and Dep. Soil and Crop Sci., Colorado State University:339382 (2015)

9. R.E. Pettit, Organic matter, humus, humate, humid acids, fulvic acids and humin. Their importance in soil fertility and plant health. www.humates.com/pdf/ORGANICMATTERPettit .pdf, (access on-line: 01.12.2015)

10. Soil Sci. Soc. of Am. (SSSA), 2008. Glossary of Soil Science Terms (2008) by Soil Science Glossary Terms Committee, (access on-line: 24.11.2014: https://www.soils.org/publications/soils-glossary\#)

11. K. Eleki, Soil management, crop rotations, and biomass removal effects on soil organic matter content, IOWA State Univ. - retrospective Theses and Dissertations, paper 15526 (2007)

12. E.S. Krull, J.O. Skjemstad, J.A. Baldock, Functions of Soil organic matter and the effect on soil properties. CSIRO Land and Water, PMB2, Glen Osmond SA 5064, (2004)

13. H.C. Buckman, N.C. Brady, Gleba $i$ jej właściwości, PWRiL, Warszawa (1971)

14. A. Fließbach, F. Eyhorn, P. Mäder, D.I. Rentsch, R. Hany, „DOK” Long-term Farming, Systems Trial: Microbial Biomass, Activity and Diversity Affect the Decomposition of Plant Residues (in): Sustainable management of soil organic matter,
CABI Publishing, CAB International: 363-369 (2001)

15. R.J. Haynes, M.S. Mokolobate, Nutr. Cyc. Agroec. 59, 47-63 (2001)

16. K. Quenea, I. Lamy, P. Winterton, A. Bermond, C. Dumat, Geoderma, 149, 3-4, 217-223 (2008)

17. G.W. Thomas, Soil Sci. Soc. Am. Proc. 39, 591, (1975)

18. R. Lal, The Final Frontier - View Point, Special Section, Science 34, 1623-1627 (2014)

19. W.H. Schlesinger, Soil organic matter: a source of atmospheric $\mathrm{CO}_{2}$, The role of Terrestrial Vegetation in the global carbon cycle (Chapter 4); Measurement by Remote Sensing (ed. Woodwell G.M.), John Willey\&Sons Ltd, (1984)

20. E.J. Russel, E.W. Russel, 1950. Soil conditions and plant growth, Longmans London, (1950), (in): E.S. Krull, J.O. Skjemstad, J.A. Baldock, Functions of Soil organic matter and the effect on soil properties, CSIRO Land and Water, PMB2, Glen Osmond SA 5064. GRDC, (2004)

21. E. Gorham, J. Sanger, Ecol. Society America Ecol. 48, 3, 492-494 (1967)

22. M.S. Darling, Oecol. 23, 2, 127-139 (1976)

23. C.F. Jordan, A World Pattern in Plant Energetics, Am. Sci. 59:425-433 (1971)

24. J.J. Hoorman, R. Islam, Agr. Nat. Res. Fact Sheet. The Ohio State University, (2010)

25. L. Zimny, R. Wacławowicz, A. Zych, Materia organiczna gleby-polisa na przyszłość. Nasza rola - gazeta rolnicza (2015) (access on line: 04.04.2017)

26. R-G. Cong, K. Hedlund, H. Andersson, M. Brady, Agr. Sys. 129, 30-39 (2014)

27. Łachacz A. (red.), Właściwości gleb - Zeszyt edukacyjny, Wyd. UWM Olsztyn (2007).

28. Kodeks Dobrej Praktyki Rolniczej. MRiRW, IUNG-PIB, FAPA, Warszawa (2004)

29. Kalkulacja dochodu bezpośredniego jęczmienia jarego, www.w-modr.pl (access on-line: 10.05.2017),

30. Kalkulacja dochodu bezpośredniego koniczyny czerwonej, www.w-modr.pl (access on-line: 10.05.2017), (wrzesień 2016)

31. Kalkulacja dochodu bezpośredniego pszenicy ozimej, www.w-modr.pl (access on-line: 10.05.2017), (wrzesień 2016)

32. European Soil Data Base Maps - Primary properties (in:) European Soil Database Centre: www.esdac.jcr.europa.eu/resource-type/europeansoil-database-maps (access on-line: 20.01.2017)

33. B.D. Kay, D.A. Angers, Soil structure, (w): Soil physics companion, Chapter 7 (ed. Warrick A.W.), CRC Press:249-295 (2001)

34. T. Stuczyński, J. Kozyra, A. Łopatka, G. Siebielec, J. Jadczyszyn, P. Koza, A. Doroszewski, R. Wawer, E. Nowocień, Studia i Rap. IUNGPiB, 7, 77-115 (2007)

35. L. Zimny, R. Wacławowicz, A. Zych, Zeszyty Probl. Post. Nauk Roln. 582, 137-146 (2015)

36. H. Dziadowiec, Zasoby materii organicznej $i$ morfogenetyczne typy próchnic leśnych (in): 
Badania ekologiczno-gleboznawcze [red. Bednarek R. i in.], PWN, Warszawa (2005)

37. C.F. Jordan, An Ecosystem Approach to Sustainable Developmnet. Energy Use Efficiency in the American South. Environmental Challenges and Sollutions 1, Springer (2013)

38. A. Kuczuk, J. Agric. Sci. 8, 4, 140-155 (2016)

39. A. Kuczuk, J. Res. Appl. Agric. Eng. 61, 4:6-14 (2016)

40. D. Pimentel, H.M. Pimentel, Food, Energy and Society, Third Edition, Taylor and Francis Group, (2008)

41. D. Pimentel, Impacts of Organic Farming on the Efficiency of Energy Use in Agriculture - An Org. Cent. State of Sci. Review, (2006)

42. A.M. Johanns, C. Chace, M. Liebmann, Energy and Economic Returns by Crop Rotation, Ag. Dec. Maker, File A1-90. Iowa State University, (2012) www.extension.iastate.edu/agdm (access on-line 09.05.2017) 